\title{
ETNOMATEMATIKA PADA AKTIVITAS PEMBUATAN BATIK MOTIF TEMBAKAU DI RUMAH PRODUKSI BATIK NHORA PENGESTU AMBULU SEBAGAI BAHAN PAKET SOAL TES
}

\author{
Endah Dwi Cahyanti ${ }^{1}$, Titik Sugiarti ${ }^{2}$, Lioni Anka Monalisa ${ }^{2}$, Susanto $^{2}$, Erfan Yudianto $^{2}$ \\ Program Studi Pendidikan Matematika, FKIP, Universitas Jember \\ Jalan Kalimantan 37 Kampus Tegalboto Jember 68121 \\ E-mail: endahdwicahyanti13@gmail.com
}

\begin{abstract}
Ethnomatematics is the science of mathematics practiced by a cultural group where the society has unconsciously applied the concept of mathematics. The purpose of this study is to describe ethnomatemics in the activity of making tobacco motifs and to produce test packages. This type of research is a qualitative research with an ethnographic approach. There are three subjects in this study, S1 as the maker of patterns / designs, color locking, and "nglorod", S2 as a dyeing and coloring, and S3 as the maker of batik cap. Data collection methods used are observation, interviews, and documentation. This research is focused on the tobacco making batik activity. The results of this study indicate the existence of ethnomatematics which includes activities: counting, measuring, and designing. Ethnomatematics in this study was made as a test package in the form of descriptive questions for even ninth grade students.
\end{abstract}

Keywords: ethnomatematics, batik making activities, test packages

\section{PENDAHULUAN}

Matematika merupakan suatu ilmu pengetahuan yang berkembang seiring dengan perkembangan kebudayaan manusia. Kline menyatakan bahwa matematika bukan pengetahuan menyendiri yang dapat sempurna karena dirinya sendiri, tetapi adanya matematika itu terutama untuk membantu dalam memahami dan menguasai permasalahan sosial, ekonomi, dan alam [1]. Matematika dibagi menjadi beberapa cabang ilmu yaitu aljabar, aritmatika, geometri, trigonometri, kalkulus [2].

Matematika merupakan ilmu yang paling dasar diantara ilmu lainnya karena segala aktivitas manusia berkaitan dengan ilmu matematika. Selain itu matematika juga dapat dikaitkan dengan kehidupan sehari-hari dikarenakan banyak aplikasi dalam kehidupan sehari-hari yang didapat dari matematika. Oleh karena itu, sangat penting bila konsep-konsep matematika dikaitkan dengan kebudayaan yang ada. Kebudayaan adalah keseluruhan sistem, gagasan, tindakan, dan hasil karya manusia dalam rangka berkehidupan masyarakat yang dijadikan milik diri manusia dengan cara belajar [3].

Budaya merupakan satu kesatuan yang utuh dan menyeluruh dari beragam perwujudan yang dihasilkan dan berlaku dalam suatu komunitas [4]. Hal tersebut

\footnotetext{
${ }^{1}$ Mahasiswa S1 Prodi Pendidikan Matematika FKIP Universitas Jember

${ }^{2}$ Dosen Prodi Pendidikan Matematika FKIP Universitas Jember
} 
memungkinkan bahwa terdapat konsep-konsep matematika yang tertanam dalam praktekpraktek budaya dan mengakui bahwa semua budaya dan semua orang mengembangkan metode unik untuk memahami dan mengubah realitas mereka sendiri, yang kemudian disebut etnomatematika. Etnomatematika digunakan untuk menunjuk matematika yang terdapat dalam lingkungan masyarakat, berkaitan dengan latar belakang sosial, ekonomi, dan budaya suatu masyarakat [5]. Aktivitas matematika yang terdapat pada aktivitas pembuatan batik tidak lepas dari aktivitas menghitung, mengukur, dan mendesain. Menghitung adalah mencari jumlah dengan cara menjumlahkan, mengurangi, mengalikan dan membagi [6]. Mengukur merupakan aktivitas yang terkait dengan penggunaan alat ukur yang sering digunakan antara lain: untuk ukuran banyaknya menggunakan istilah: seikat atau satu ikat, sepotong, satu keranjang besar. Terdapat juga ukuran yang baku dalam matematika seperti meter (m) untuk menyatakan panjang, sekon (s) untuk menyatakan waktu, kilogram (kg) untuk menyatakan massa, dan kelvin (k) untuk menyatakan suhu [7]. Mendesain merupakan aktivitas yang berhubungan dengan matematika terapan, aktivitas pendesainan yang dilakukan masyarakat berkaitan dengan kegiatan membuat rancangan dan telah diterapkan oleh semua jenis suku dan budaya [8].

Seni membatik diwariskan secara turun temurun mulai dari cara sederhana manual, dan saat ini perkembangan batik dikenal dengan batik cap dengan corak motif modern sehingga memberikan kesan modern dan lebih update sesuai zamannya. Batik telah menjadi warisan budaya bangsa Indonesia dan setiap daerah memiliki motif batik yang khas seperti Kabupaten Jember dengan batik bermotif daun tembakau [9]. Melalui potensi tanaman tembakau ini, Kabupaten Jember telah lama terkenal dan melegenda sebagai "Kota Tembakau" yang menjadi salah satu daerah produsen dan penghasil tembakau terbesar dengan produk yang berkualitas. Menurut teknik pembuatannya, batik dibedakan menjadi 2 yaitu batik tulis dan batik cap. Nilai batik tulis tergantung dari tingkat kesulitan pencantingannya. Batik cap adalah kain mori dicap saja tanpa disempurnakan dengan canting [10]. Adapun tahapan-tahapan dalam proses pembuatan batik tulis dan batik cap seperti membuat pola atau desain batik, mencanting/mengecap, mewarna, penguncian warna, "nglorod", dan penjemuran. Dari aktivitas pembuatan batik motif tembakau ini terdapat konsep-konsep matematika didalamnya. Konsep matematika yang ada pada aktivitas pembuatan batik motif tembakau di Rumah Produksi Batik Nhora Pangestu dapat dijadikan sebagai bahan paket soal tes untuk mengetahui hasil dari kegiatan pembelajaran yang ditujukan untuk kelas IX SMP/MTs. Paket tes memuat soal-soal 
uraian yang terkait dengan etnomatematika pada aktivitas pembuatan batik motif tembakau di Rumah Produksi Batik Nhora Pangestu Ambulu.

\section{METODE PENELITIAN}

Penelitian ini merupakan penelitian deskriptif kualitatif dengan pendekatan etnografi. Dalam penelitian ini pendekatan etnografi digunakan untuk mendeskripsikan konsep matematika yang terdapat pada aktivitas pembuatan batik motif tembakau di Rumah Produksi Batik Nhora Pangestu Ambulu. Pengambilan data penelitian ini dilakukan di Jl. Kamboja Desa Tutul Tegalsari, Kecamatan Ambulu, Kabupaten Jember dan terfokus pada aktivitas pembuatan batik motif tembakau. Subjek dalam penelitian ini 3 orang pembatik yaitu S1 sebagai pembuat pola/desain, penguncian warna, dan "nglorod", S2 sebagai pencanting dan pewarnaan, dan S3 sebagai pembuat batik cap. Metode pengumpulan data yang digunakan yaitu observasi, wawancara, dan dokumentasi. Untuk mempermudah mencapai tujuan penelitian, maka langkah pertama yang harus dilakukan adalah pemilihan tempat dan subjek penelitian.

Langkah kedua adalah penyusunan instrumen penelitian dengan membuat instrumen penelitian yang digunakan sebagai pedoman observasi dan pedoman wawancara. Langkah ketiga adalah draf instrumen yang berisi tentang rancangan atau konsep dari suatu instrumen penelitian yang diajukan kepada validator. Langkah keempat adalah validasi draft instrumen pedoman observasi dan wawancara divalidasi oleh validator. Langkah kelima adalah instrumen yang telah valid dapat dilanjutkan ke tahap berikutnya. Langkah keenam adalah pengumpulan data yang diperoleh dengan melakukan observasi, wawancara, dan dokumentasi. Observasi pada penelitian ini yaitu mengamati secara langsung aktivitas etnomatematika dalam pembuatan batik motif tembakau. Wawancara dilakukan untuk memperoleh data yang lebih mendalam tentang aktivitas pembuatan batik motif tembakau sehingga dapat memperkuat hasil observasi. Langkah ketujuh adalah analisis data dengan menyusun data yang sesuai dengan fokus kajian masalah dan tujuan penelitian. Langkah kedelapan yaitu penyusunan paket tes mengenai konsep matematika yang terdapat pada aktivitas pembuatan batik motif tembakau di Rumah Produksi Batik Nhora Pangestu Ambulu. Langkah kesembilan adalah menyimpulan hasil analisis data yang diperoleh pada tahap sebelumnya. 


\section{HASIL DAN PEMBAHASAN}

Berdasarkan hasil observasi dan wawancara dengan ketiga subjek penelitian, terdapat etnomatematika pada aktivitas pembuatan batik motif tembakau di Rumah Produksi Batik Nhora Pangestu Ambulu diantaranya aktivitas menghitung, mengukur, dan mendesain.

\section{A. Aktivitas Menghitung}

Aktivitas menghitung muncul ketika pembatik menghitung kebutuhan alat dan bahan untuk satu kain batik. Pertanyaan dan jawaban S1 dalam menghitung kebutuhan alat dan bahan untuk satu kain batik sebagai berikut.

P1006 Bagaimana cara mbak menghitung kebutuhan alat dan bahan untuk satu kain batik?

S1006 Sebenarnya kalau penelitian langsung ngehitung itu nggak ada mbak cuma proses. Kalau full motif itu satu ons malamnya. Kalau waterglassnya itu satu kilo bisa tiga kain. Kalau warna itu kan kita satu liter itu butuhnya tiga puluh gram. Nah itu kalau satu liter dibuat warna dasar bisa untuk 3-4 kain. Yang nggak bisa dihitung itu coletannya itu yang kecil-kecil soalnya tergantung motifnya seberapa banyak gitu. Tapi kalau dihitungan besarnya 1 liter itu bisa 3-4 kain.

Kebutuhan bahan dapat dilihat dari seberapa penuh motif yang diinginkan. Umumnya untuk mencanting satu kain batik membutuhkan satu ons malam dan penggunaan 1 kilogram waterglass dapat digunakan untuk 3-4 kain. Sementara itu, untuk pencampuran antara air dan pewarna bubuk yaitu 1 liter air dan 30 gram pewarna bubuk dan dapat digunakan untuk 3-4 kain sebagai warna dasar.

Aktivitas menghitung selanjutnya muncul saat pembatik menghitung kebutuhan malam yang digunakan untuk mencanting dan mengecap. Pertanyaan dan jawaban S2 dalam menghitung kebutuhan malam untuk mencanting yang dilakukan oleh pembatik sebagai berikut.

P2009 Bagaimana cara mbak mengukur malam untuk sehelai kain?

S2009 Tergantung motifnya ya mbak. Nah jadi kalau untuk full itu paling berapa ya sekitar satu ons. Tapi kalau untuk yang jarang-jarang itu dikit aja paling berapa dua ratus sampai tiga ratus gram gitu aja. Semua tergantung motifnya mbak.

Kebutuhan malam untuk mencanting satu kain batik dapat dilihat dari motif yang dibuat untuk motif penuh membutuhkan 1 ons malam. Jika motif tidak penuh maka hanya membutuhkan 200-300 gram sedangkan kebutuhan malam untuk mengecap satu kain batik membutuhkan 1 ons malam. 
Aktivitas menghitung juga muncul saat pembatik menghitung warna yang digunakan untuk sehelai kain. Pertanyaan dan jawaban S2 dalam menghitung pencampuran warna yang dilakukan oleh pembatik sebagai berikut.

P2022 Bagaimana cara mbak menentukan warna apa saja yang dibutuhkan pada sehelai kain?

S2022 Tergantung kebutuhan. Jika teknik celup 1 liter pewarna bisa 3-4 kain.

Kebutuhan warna pada sehelai kain dapat dilihat dari banyaknya kebutuhan warna yang digunakan. Contohnya pada teknik celup, dibutuhkan 1 liter pewarna untuk mewarnai 3-4 kain.

Aktivitas menghitung lainnya muncul ketika pembatik mencampurkan warna yaitu dapat dilihat dari warna yang diinginkan. Pertanyaan dan jawaban S2 dalam menghitung pencampuran warna yang dilakukan oleh pembatik sebagai berikut.

P2024 Bagaimana cara mbak mencampur warna-warna sehingga menghasilkan warna yang diinginkan?

S2024 Biasanya untuk 1 liter air itu membutuhkan warna 30 gram. Dan seliter warna itu kalau pakai teknik celup bisa menghasilkan 3-4kain. Untuk proses pencampuran warna itu banyak banget macamnya. Ada yang perbandingannya $1: 1$ ada $1: 2$ tergantung warna yang diinginkan.

Dalam penggunaan 1 liter air membutuhkan 30 gram pewarna bubuk dan dapat menghasilkan 3-4 kain. Adapun cara lain dalam mencampurkan pewarna yaitu dengan perbandingan warna $1: 1$ atau $1: 2$. Pada aktivitas ini terdapat konsep matematika berupa perbandingan.

Aktivitas menghitung lainnya muncul ketika pembatik menghitung banyaknya waterglass yang digunakan saat proses penguncian warna. Pertanyaan dan jawaban S1 dalam menghitung kebutuhan waterglass yang dilakukan oleh pembatik sebagai berikut.

P1034 Bagaimana cara mbak menghitung kebutuhan waterglass dalam penguncian warna?

S1034 Kalau waterglass itu satu kilo itu bisa tiga kain.

Waterglass merupakan bahan keras dan jika terkena kulit akan iritasi. Tempat plastik yang digunakan di Rumah Produksi Batik Nhora Pangestu berupa jerigen plastik. Kebutuhan waterglass yaitu 1 kilogram waterglass dapat digunakan untuk 3 kain maka perhitungan waterglass yaitu 1/3 liter atau 0,33 liter per kain. 
Pada proses "nglorod", tidak terdapat ketentuan khusus saat menghitung kebutuhan air dalam proses "nglorod". Pertanyaan dan jawaban S1 dalam menghitung kebutuhan air saat proses "nglorod" yang dilakukan oleh pembatik sebagai berikut.

P1039 Bagaimana cara mbak menghitung kebutuhan air pada proses "nglorod"?

S1039 Nggak dihitung karena sistemnya air mengalir. Tapi kalau pas ngerebusnya itu ya pakai panci tapi nggak penuh paling cuma tiga per empat bagian saja soalnya nanti kalau penuh kan tumpah airnya pas kainnya dimasukkan.

Air yang dibutuhkan hanya 3/4 bagian dari panci yang digunakan dan satu panci dapat digunakan untuk 10 kain. Berdasarkan observasi yang dilakukan, panci yang digunakan berukuran diameter $30 \mathrm{~cm}$ dan tinggi $50 \mathrm{~cm}$. Pada aktivitas ini terdapat aktivitas menghitung ketika pembatik menghitung kebutuhan air saat proses "nglorod". Perhitungan banyaknya air yang digunakan untuk proses " $n g l o r o d$ " yaitu sebagai berikut. Panci berbentuk tabung dengan $d=30 \mathrm{~cm}$ dan $t=50 \mathrm{~cm}$. Karena air yang dibutuhkan $3 / 4$ dari tinggi panci sehingga $t_{\text {air }}=\frac{3}{4} \times 50=37,5 \mathrm{~cm}$

$$
\begin{aligned}
V_{\text {air }} & =\pi \cdot r^{2} \cdot t_{\text {air }} \\
& =3,14 \cdot 15^{2} \cdot 37,5 \\
& =26,49375 \text { liter }
\end{aligned}
$$

Aktivitas menghitung lainnya muncul ketika pembatik menghitung banyaknya motif dalam sehelai kain. Pertanyaan dan jawaban S1 menghitung banyak motif pada sehelai kain yang dilakukan oleh pembatik sebagai berikut.

P1021 Bagaimana cara mbak menghitung banyaknya motif pada sehelai kain?

S1021 Kadang 1 motif itu cukup mbak, yang lainnya bisa jadi motif tambahan itu juga bisa 3-4 motif tambahan. Yang jadi ikonnya biasanya 1 motif mbak.

Pada kain batik, umumnya motif utama terdiri dari 1 motif dan untuk motif tambahan hingga 3-4 motif.

Saat proses pengecapan, pembatik meletakkan cap pada kain hanya satu kali karena jika lebih dari satu kali suhu mengalami penurunan sehingga malam tidak tembus sampai ke sisi kain yang dapat mengakibatkan tidak rapi jika dilakukan proses pewarnaan.

Aktivitas menghitung selanjutnya muncul ketika pembatik menghitung banyaknya cap pada kain.

P3009 Bagaimana cara mbak menghitung banyaknya cap pada sehelai kain?

S3009 Tergantung memposisikan capnya mbak. Jarak antar capnya juga. Misal jarak antar cap $10 \mathrm{~cm}$ dan capnya $10 \mathrm{~cm}$ kalau cuma digeser kebawah ya sekitar 4 
kali geser kesampingnya mungkin bisa 9 kali geser. Belum lagi kalau bentuknya zig-zag atau selang-seling gitu.

Banyaknya cap yang dihasilkan tergantung ketika pembatik memposisikan cap dan jarak antar cap. Misalkan jarak antar cap yaitu $10 \mathrm{~cm}$ dan ukuran cap $10 \mathrm{~cm}$ maka jika digeser ke bawah bisa sampai 4 kali geser dan digeser ke samping bisa sampai 9 kali geser. Total banyaknya motif adalah sebagai berikut.

Misal

$$
\begin{gathered}
a=\text { geser ke bawah } \\
b=\text { geser ke samping }
\end{gathered}
$$

Sehingga

$$
\begin{aligned}
\text { Total Motif } & =(a+1) \times(b+1) \\
& =(4+1) \times(9+1) \\
& =50
\end{aligned}
$$

nb : ditambah 1 karena posisi awal tidak dihitung sebagai pergeseran

Jadi banyaknya motif yang dihasilkan disehelai kain dengan ketentuan di atas yaitu 50 motif. Pada aktivitas ini terdapat konsep matematika berupa translasi.

\section{B. Aktivitas Mengukur}

Aktivitas mengukur muncul ketika pembatik mengukur sehelai kain batik. Pembatik mengukur kain dengan menggunakan meteran dan memotong kain sesuai dengan pesanan. Pada umumnya kain dipotong dengan ukuran $2 \times 1,15$ meter. Untuk ukuran besar biasanya pembatik memotong kain dengan ukuran 2,5 meter atau 3 meter. Ketika warna yang digunakan adalah warna alam maka panjang kain dilebihkan menjadi 2,20 meter.

Aktivitas mengukur lainnya muncul ketika pembatik mengukur waterglass yang dicampurkan dengan air. Pertanyaan dan jawaban S1 dalam mengukur waterglass yang dicampurkan dengan air yang dilakukan oleh pembatik sebagai berikut.

P1036 Apa ada perhitungan dalam pencampuran waterglass dengan bahan lainnya?

S1036 Disini pakai waterglass yang sudah dicampur mbak. Sebenernya waterglass itu campurannya air sama soda as. Biasanya airnya $1 / 3$ dari waterglassnya.

Terdapat 2 macam waterglass yaitu berupa waterglass yang masih kental belum dicampur dengan air dan waterglass yang telah dicampurkan dengan air. Menurut pembatik jika membeli waterglass yang masih kental maka perlu mecampurkan air 
sebanyak 1/3 dari banyaknya waterglass. Jadi jika waterglass yang digunakan sebanyak 3 liter maka membutuhkan campuran 1 liter air.

Adapun aktivitas mengukur selanjutnya yaitu ketika pembatik membuat pola/desain batik. Pertanyaan dan jawaban S1 mengukur ketepatan pertemuan pada pola/desain batik yang dilakukan oleh pembatik sebagai berikut.

P1020 Bagaimana cara mbak menentukan ketepatan pertemuan pada pola/desain batik?

S1020 Awalnya dilipat dulu kertasnya jadi 4 bagian terus sambungan lipatannya digambar dulu. Dilipat lagi jadi 4 bagian kemudian digambar lagi yang ada sambungannya. Setelah itu baru gambar yang bagian tengahnya. Jadi intinya dilipat dulu biar tahu dimana nyambungnya.

Pola/desain yang dibuat oleh pembatik ujung atau tepinya tidak selalu bertemu. Ujung atau tepi yang bertemu menghasilkan pola/desain yang nyambung atau tidak terpotong. Untuk motif yang terdiri dari satu motif maka pola/desain tidak perlu nyambung atau ujungnya tidak bertemu karena untuk menggambar motif pada kain hanya perlu digeser seperti ke bawah, ke samping atau diputar. Langkah awal dalam membuat pola/desain di kain yaitu dengan melipat kertas menjadi 4 bagian kemudian menggambar pola/desain batik pada sambungan lipatan dari kertas HVS. Setelah itu lipat lagi menjadi 4 bagian dan gambar pola/desain batik disambungan lipatan kertas.

Aktivitas mengukur selanjutnya muncul ketika pembatik mengukur garis tepi pada kain. Garis tepi berfungsi sebagai lipatan agar warna batik tidak terlipat saat dijahit. Kain batik yang dibuat tidak selalu diberi tepi. Kain diberikan garis tepi jika motif yang dibuat tidak penuh atau jarang-jarang. Ukuran garis tepi biasanya berukuran $7 \mathrm{~cm}$ untuk bagian samping dan $10 \mathrm{~cm}$ untuk bagian bawah kain.

Aktivitas mengukur lainnya muncul ketika pembatik menjelaskan ukuran cap di Rumah Produksi Batik Nhora Pangestu. Terdapat 10 macam cap di Rumah Produksi ini, diantaranya 4 cap motif tembakau dan 6 cap merupakan motif tambahan seperti kopi, burung, bunga, dan "ukel". Motif cap didesain oleh pembuat pola/desain batik di Rumah Produksi Batik Nhora Ambulu. Ukuran cap di Rumah Produksi Batik Nhora Pangestu yaitu $8 \times 8 \mathrm{~cm}, 4 \times 5 \mathrm{~cm}$, dan $10 \times 10 \mathrm{~cm}$.

Selain itu, aktivitas mengukur juga muncul ketika pembatik mengecap pada kain agar simetris. Pertanyaan dan jawaban S3 dalam mengecap kain agar simetris yang dilakukan oleh pembatik sebagai berikut. 
P3011 Bagaimana cara mbak mengecap kain agar simetris?

S3011 Awal itu pakai penggaris kayu mbak jadi diukur jaraknya berapa gitu. Untuk selanjutnya udah tau ukuran awalnya mbak jadinya nggak perlu pakai penggaris lagi.

Jarak motif diukur sesuai dengan pesanan. Saat mengukur jarak antar motif hanya dilakukan satu kali saat pertama mengecap untuk selanjutnya pembatik tidak menggunakan penggaris dalam mengukur jarak antar motif.

\section{Aktivitas Mendesain}

Aktivitas mendesain muncul ketika pembatik mendesain motif batik. Pertanyaan dan jawaban S1 dalam mendesain motif batik yang dilakukan oleh pembatik sebagai berikut.

P1013 Bagaimana cara mbak membuat pola/desain batik pada kertas HVS?

S1013 Kita desain motifnya di kertas HVS. Untuk pengarangannya kan untuk sesuai request mbak. Seumpama motif yang diinginkan itu daun tembakau. Jadi kita karang kan daun tembakau terus tambahannya kita ambil referensi dari google. Terus digambarnya dari sambungan-sambungan kertas yang udah di lipat itu.

Pembatik mendesain motif sesuai dengan pesanan. Dalam mendesain terdapat motif utama dan motif tambahan dengan mengambil referensi dari google atau dengan ide sendiri. Saat menggambar desain pada kertas HVS, langkah awal yaitu dengan melipat terlebih dahulu kertas HVS. Menggambar motif dimulai dari tepi lipatan HVS sehingga sebelum pembatik mendesain pola pada kertas HVS, pembatik terlebih dahulu melipat kertas menjadi 4 bagian kemudian melipat ujung kanan dan kiri hingga tepi kertas menyatu seperti gambar berikut ini.

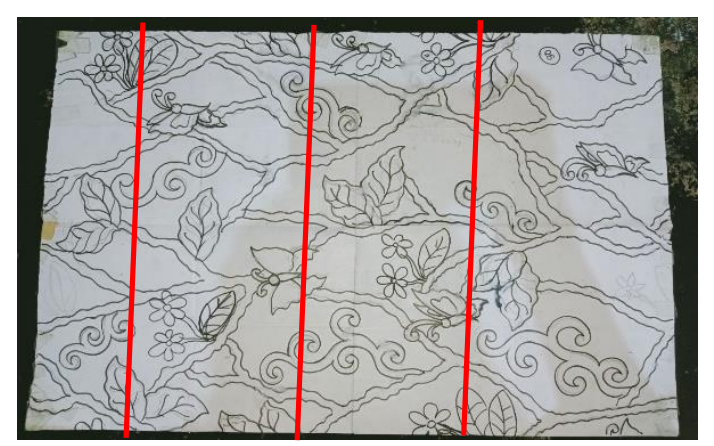

Gambar 1. Desain satu lembar HVS dilipat menjadi 4 bagian 


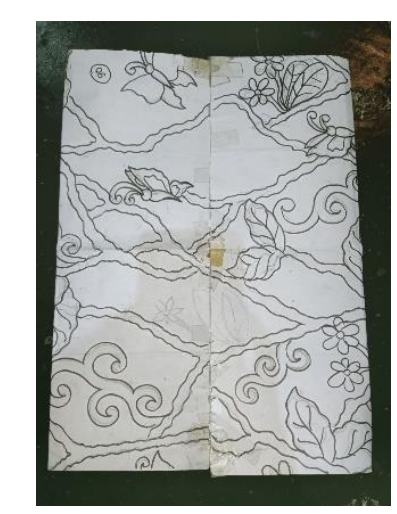

Gambar 2. Tepi kanan dan kiri dipertemukan

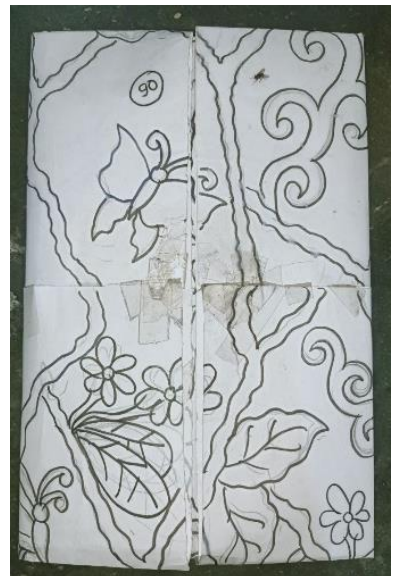

Gambar 3. Lipat menjadi 4 bagian kemudian dipertemukan kembali

Aktivitas mendesain muncul ketika pembatik membuat pola/desain pada kain yaitu dengan cara "ngeblat". Kain yang digambarkan pola/desainnya diletakkan diatas kertas HVS/kalkir yang terdapat motifnya kemudian kain digeser ke samping dan ke atas. Untuk kain berukuran $2 \times 1,15$ meter maka menggeser kain ke samping membutuhkan 1 kali dan keatas hanya sedikit hingga semua bagian kain tertutup oleh motif. Jika hanya satu motif maka bisa digeser beberapa kali sesuai pesanan. Adapun pesanan batik dengan pola baju maka satu helai kain batik terdapat 3 bagian. Bagian tengah biasanya digunakan untuk punggung dan pinggir digunakan untuk bagian depan.

Aktivitas mendesain selanjutnya muncul ketika pembatik meletakkan posisi cap. Pertanyaan dan jawaban S3 dalam meletakkan cap pada kain yang dilakukan oleh pembatik sebagai berikut.

P3010 Biasanya kalau mengecap itu apa ada polanya mbak?

S3010 Ada mbak. Misalnya capnya tegak jalannya kesamping keatas dengan jarak yang sama, ada yang sebaris tegak terus atasnya tidur capnya, ada lagi yang kayak nyusun batu bata itu, ada yang nyusunnya diagonal jadi miring-miring gitu, dan banyak lagi mbak. Jadi banyak pola saat mengecap cap dikain. 
Beberapa pola yang dilakukan oleh pembatik saat mengecap seperti meletakkan cap tegak dan berjalan ke samping, meletakkan cap miring dan berjalan ke samping, meletakkan cap seperti batu bata, dan meletakkan cap baris pertama tegak dan baris selanjutnya tidur. Adapun macam-macam posisi meletakkan cap sebagai berikut.
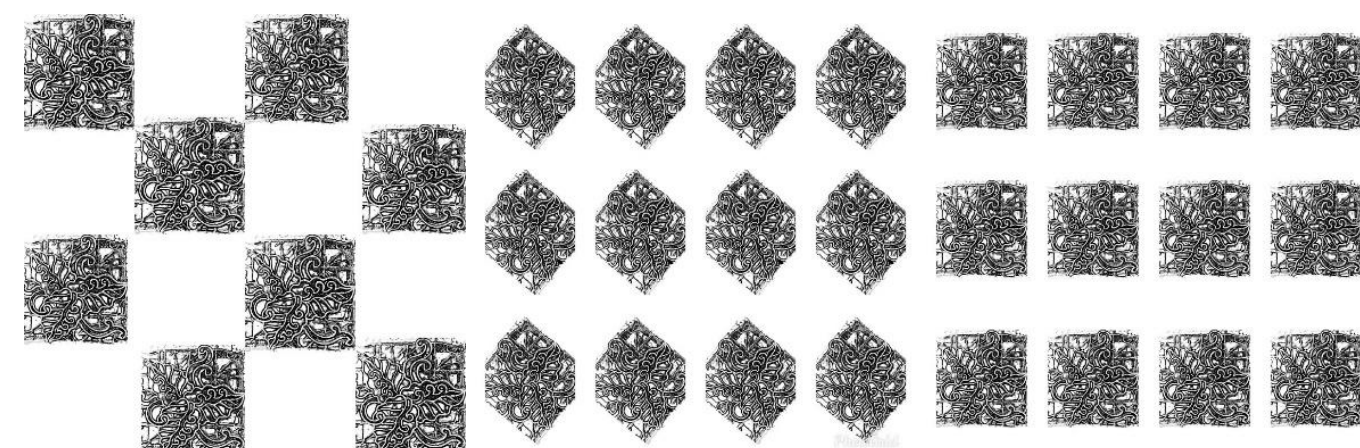

Gambar 4. Ilustrasi posisi peletakkan cap

Etnomatematika yang diperoleh pada penelitian ini adalah etnomatematika pada aktivitas menghitung, mengukur, dan mendesain. Konsep matematika yang ada pada aktivitas pembuatan batik motif tembakau dapat dijadikan sebagai bahan paket soal tes. Paket soal tes bertujuan untuk mengetahui hasil dari kegiatan pembelajaran. Paket soal tes ini diberikan pada siswa kelas IX SMP/MTs.

Berikut adalah paket soal tes yang berkaitan dengan etnomatematika pada aktivitas pembuatan batik motif tembakau di Rumah Produksi Batik Nhora Pangestu Ambulu. 


\section{Paket Soal Tes}

$\begin{array}{ll}\text { Satuan Pendidikan } & \text { : SMP } \\ \text { Mata Pelajaran } & : \text { Matematika } \\ \text { Kelas } & : \text { IX } \\ \text { Alokasi Waktu } & : 2 \times 40 \text { menit }\end{array}$

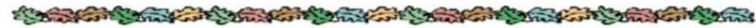

Petunjuk :

> Berdoalah terlebih dahulu sebelum mengerjakan tes berikut.

> Kerjakan pada lembar jawaban yang telah disediakan dengan menuliskan nama dan nomor absen.

$>$ Bacalah dengan cermat

> Kerjakan secara individu dan tanyakan pada guru apabila terdapat soal yang kurang jelas.

Jawablah soal-soal dibawah ini dengan rinci dan benar!

1. Mbak Ningrum merupakan salah satu pembatik yang bertugas untuk mencanting kain. Untuk mencanting satu kain batik motif dibutuhkan 300 gram malam. Pesanan yang diterima mbak ningrum sebanyak 425 helai kain. Berapa malam yang harus dipersiapkan oleh mbak ningrum untuk mencanting semua pesanan?

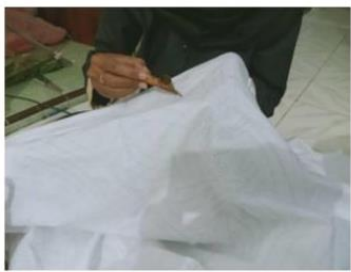

Gambar 1. Mencanting

2. Dalam proses penguncian warna pada kain batik seperti gambar 2 , pembatik menggunakan bahan berupa waterglass yang dicampur dengan air. Perbandingan air dan waterglass adalah 1:3. Campuran waterglass dengan air sebanyak 1 kilogram dapat mengunci warna pada 4 helai kain Jika pembatik ingin mengunci warna pada 32 helai kain, maka berapa banyak masing masing waterglass dan air yang dibutuhkan?

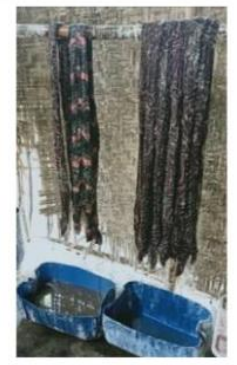

Gambar 2. Penguncian warna 


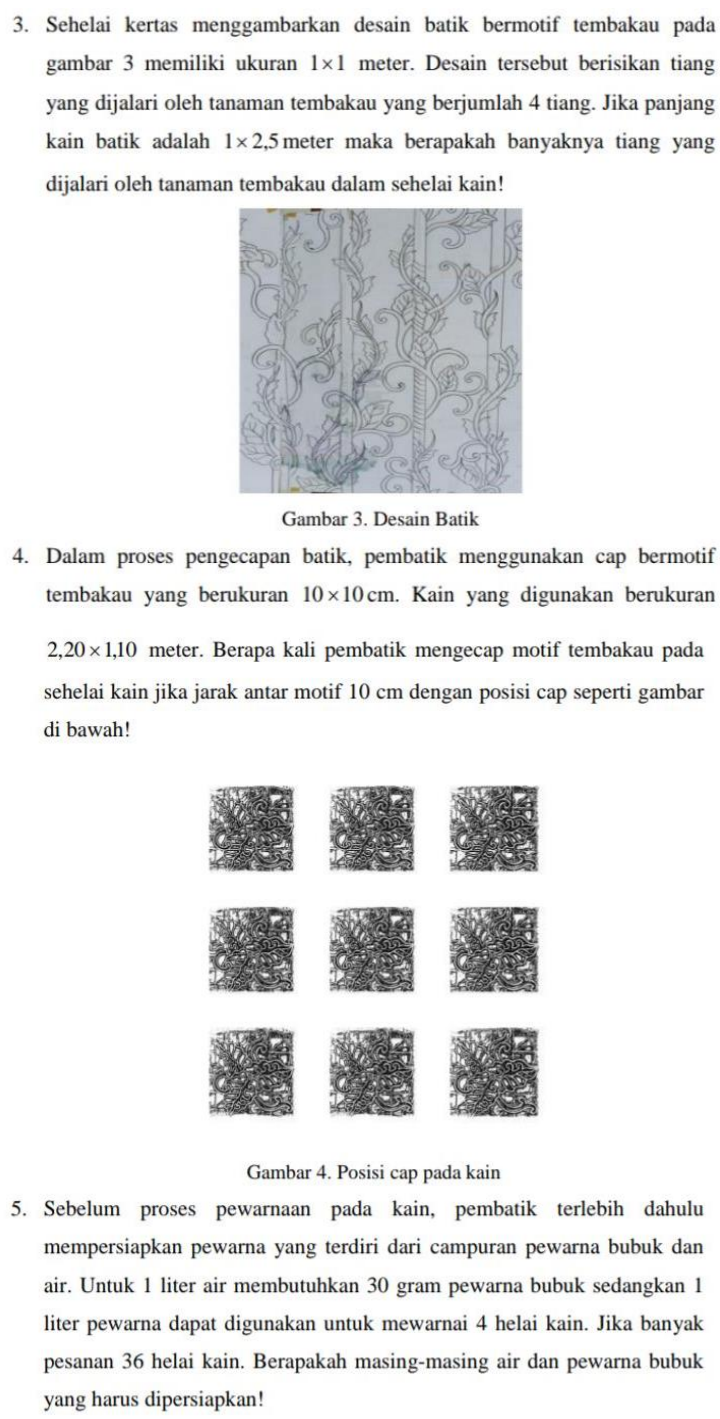

https://bit.ly/paketsoaltes

\section{KESIMPULAN}

Berdasarkan hasil analisis dan pembahasan, dapat disimpulkan bahwa terdapat etnomatematika pada aktivitas pembuatan batik motif tembakau yang terdiri dari konsep matematika yaitu aktivitas menghitung, aktivitas mengukur, dan aktivitas mendesain. Aktivitas menghitung muncul pada saat pembatik menghitung alat dan bahan untuk sehelai kain, menghitung kebutuhan malam, menghitung banyaknya warna yang digunakan dalam sehelai kain, menghitung pencampuran warna, menghitung kebutuhan waterglass, menghitung kebutuhan air pada saat "nglorod", menghitung banyaknya motif dalam sehelai kain, menghitung peletakan cap pada kain, dan menghitung banyaknya cap pada kain.

Etnomatematika pada aktivitas mengukur juga muncul saat pembatik mengukur sehelai kain. Ketika mengukur pencampuran waterglass dengan air dengan ukuran 1/3 
dari banyaknya waterglass. Saat menggambarkan pola/desain pada kain hanya perlu digeser ke bawah, ke samping dan untuk satu motif dengan diputar, selain mengukur juga terdapat konsep matematika seperti translasi dan rotasi. Etnomatematika mengukur selanjutnya ketika mengukur garis tepi pada kain batik, mengukur ukuran cap yang digunakan, dan mengecap pada kain agar simetris.

Etnomatematika pada aktivitas mendesain juga muncul dalam membatik diantaranya ketika pembatik mendesain pola/desain pada kertas HVS dan kalkir, membuat pola/desain pada kain, dan meletakkan posisi cap pada kain. Adapun pesanan batik dengan pola baju untuk satu helai kain terdapat 3 bagian. Terdapat beberapa pola saat meletakkan posisi cap pada kain seperti cap diletakkan tegak, miring, tidur, dan selang-seling. Hasil etnomatematika yang telah ditemukan digunakan sebagai bahan paket soal tes. Paket soal tes berisikan soal-soal uraian dengan materi perbandingan yang ditujukan pada kelas IX SMP/MTs.

\section{DAFTAR PUSTAKA}

[1] Fajar, F. A., Sunardi, \& Yudianto, E. (2018). Etnomatematika Pembuatan Kerajinan Tangan Anyaman Bambu Masyarakat Osing di Desa Gintangan Banyuwangi sebagai Bahan Ajar Geometri. Kadikma, 9(3), 97-108.

[2] Purba, V. L. (2014). Pembuatan Aplikasi Rumus dan Penghitungan Matematika Populer "MATPOP" Berbasis Android. Yogyakarta.

[3] Koentjaraningrat. (2009). Pengantar Ilmu Antropologi. Edisi revisi. Jakarta: Rineka Cipta.

[4] Pratama, L. D., \& Lestari, W. (2017). Eksplorasi Etnomatematika Petani dalam Lingkup Masyarakat Jawa. SEMINAR NASIONAL MATEMATIKA DAN PENDIDIKAN MATEMATIKA (2ndSENATIK), 91-97. Semarang: Universitas PGRI Semarang.

[5] Safitri, D. (2015). Eksplorasi Konsep Matematika pada Permainan Masyarakat Melayu Sambas. Jurnal Pontianak, 1-12.

[6] Fadlilah, U., Trapsilasiwi, D., \& Oktavianingtyas, E. (2015). Identifikasi Aktivitas Etnomatematika Petani Padi pada Masyarakat Jawa di Desa Setail. Kadikma, 6(3), 45-46.

[7] Wahyuni, I. (2016). Eksplorasi Etnomatematika Masyarakat Pesisir Selatan Kecamatan Puger Kabupaten Jember. FENOMENA, 15(2), 225-238.

[8] Hartoyo, A. (2012). Etnomatematika pada Budaya Masyarakat Dayak Perbatasan Indonesia-Malaysia. Jurnal Penelitian Pendidikan, 13(1), 19-40.

[9] Hidayat, M. (2018). Motif Daun Tembakau, Ciri Khas Batik Jember.https://www.cendananews.com/2018/10/motif-daun-tembakau-ciri-khasbatik-jember.html [Diakses pada 10 juni 2019]

[10] Tjahjani, I. (2013). Yuk Mbatik! Panduan Terampil Membatik untuk Siswa. Jakarta:Erlangga. 